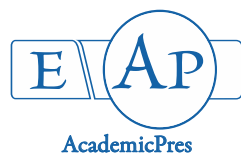

\title{
Observations on the Activities of Certain Serum Enzymes and Levels of Some Biochemical Parameters in Spent Horses with Liver Damage
}

\author{
Onyinyechukwu A. AGINA*, John I. IHEDIOHA \\ University of Nigeria, Faculty of Veterinary Medicine, Department of Veterinary Pathology and Microbiology, Nsukka, \\ Nigeria; onyinye.noel@unn.edu.ng (*orrespondingauthor)
}

\begin{abstract}
Clinical biochemistry tests are one of the tests designed to assess the functional status of the liver in domestic animals and man. This study evaluated the activities of some serum enzymes and the level of some biochemical parameters in horses with acute and chronic liver damage. This study was carried out in Nigerian horses presented for sale at the Obollo Afor horse depot, Udenu Local Government Area, Enugu State Nigeria. A total of 100 adult Nigerian horses of either sex were studied once a week for a period of 24 weeks. Serum biochemistry parameters indicated for the assessment of liver function were evaluated following standard procedures. These parameters include: Alanine aminotransferase (ALT), aspartate aminotransferase (AST), alkaline phosphatase (ALP), total proteins, albumin, globulin, total cholesterol, total bilirubin and urea. Based on the outcome of the serum biochemistry evaluation, the horses were assigned into 3 groups namely: apparently healthy horses (Group 1), horses with biochemical markers of acute liver damage (Group 2) and horses with biochemical markers of chronic liver damage (Group 3). The mean serum ALT, AST, ALP and total bilirubin values of group 2 horses were significantly $(p<0.05)$ higher than those of groups 1 and 3 horses. The mean serum albumin value of group 2 horses was significantly $(p<0.05)$ lower than that of groups 1 and 3 horses. There was no significant $(p>0.05)$ difference in the mean serum urea value of group 2 and 3. A significantly $(p<0.05)$ lower serum creatinine value was observed in group 2 horses. There were no significant $(p>0.05)$ differences in the mean serum total protein, globulin and cholesterol values across the groups. In the spent horses, acute liver damage was characterized by increased serum ALT, AST and ALP activities, and decrease in creatinine level, hyperbilirubinemia, slight hypoalbuminemia, normal total protein, globulin and cholesterol levels while chronic liver damage was characterized by decreased serum ALT activity, normal serum AST and ALP activities, decreased serum urea level, normal total protein, albumin, globulin, total bilirubin and cholesterol levels.
\end{abstract}

Keywords: acute; chronic; liver damage; serum biochemistry; spent horses

\section{Introduction}

The liver is an organ of diverse metabolic functions. These functions include bile production and excretion, excretion of bilirubin, cholesterol, hormones and drugs, metabolism of lipids, carbohydrates and proteins, enzyme activation, storage of glycogen, vitamins and minerals, synthesis of plasma proteins such as albumin and clotting factors, blood detoxification and purification (Coles, 1986; Stockham and Scott, 2008). When infectious agents and/or their products damage liver cells, changes in the liver functional ability and consequent alteration in synthetic, excretory and storage ability of the liver occurs.
Hepatocellular integrity and liver function are evaluated by quantitative determinations of the activity concentration of many enzymes and the levels of certain biochemical substances, hormones in blood, plasma or serum (Coles, 1986).

A variety of laboratory tests have been developed to detect alterations in hepatocellular integrity and/or liver function. These laboratory tests also help to estimate the extent of organ damage and efficacy of therapy instituted to treat the disorders (Coles, 1986; Sirois, 1995). These laboratory tests include determination of serum activity of certain enzymes, and tests evaluating hepatic secretion, excretion or synthetic abilities. Alterations in serum enzyme activity occurs when there is increased release from damaged cells due to hepatocellular injury/necrosis, decrease in 
306

functional mass of hepatocytes, induction of enzyme synthesis by certain drugs, cell proliferation seen in bile duct hyperplasia or neoplasia (osteosarcoma), decreased enzyme clearance from plasma/serum and ingestion and absorption of colostral enzymes such as gamma glutamyltransferase and alkaline phosphatase (Stockham and Scott, 2008). It can also occur following physical obstruction to biliary flow or metabolic abnormalities that lead to cholestasis (Coles, 1986; Stockham and Scott, 2008). A decrease in plasma/serum activities of most liver enzymes may not be of diagnostic importance. Such decreases may be attributed to poor sample handling (degraded enzymes), presence of an inhibitor (e.g. anticoagulant), reference interval that is not appropriate for a given animal species, or specifically because of decreased functional mass of tissue/organ of origin (Stockham and Scott, 2008).

In mammals, the most commonly used markers of liver (hepatocellular) disease/damage are the alanine aminotransferase (ALT), aspartate aminotransferase (AST) and alkaline phosphatase (ALP). Aspartate aminotransferase is a cytoplasmic enzyme, which occurs in almost all cells. Very high levels of it are found in the liver, erythrocytes, cardiac and skeletal muscle cells (Bain, 2003). Therefore, increased serum AST activity occurs when there is hepatic necrosis and sublethal injury or massive cardiac and skeletal muscle necrosis. As a leakage enzyme, the assessment of its serum activity is diagnostically important in large animals (horses and cattle) and small ruminants (goat and sheep), in detecting liver and muscle diseases. In the horse, elevated AST values are observed in azoturia, hepatitis, chronic active hepatitis, septicemia and intestinal complications (Stockham and Scott, 2008). It is also associated with infectious diseases of horses such as equine salmonellosis (Radostits et al., 2007). Increased serum activities in the horse also have been associated with halothane and chloroform anaesthesia, and carbon tetrachloride poisoning. It has been reported to be of value in predicting copper poisoning. Decrease in serum aspartate aminotransferase activity occurs in conditions of chronic hepatic damage due to a decrease in functional hepatic mass (Messer and Johnson, 1994).

Serum alanine aminotransferase (ALT) activity also evaluates hepatocellular integrity in small animals such as dogs, cats, rats, guinea pigs, and in man. Highest level of ALT is found in the hepatocytes (Bain, 2003). Increased serum activity occurs in conditions of hepatic degeneration and necrosis. The magnitude of increase is proportional to the number of hepatocytes affected in acute liver damage. It is usually presumed that ALT is not to be a useful indicator of hepatic damage in the horse and cattle due to its relatively low levels in hepatocytes compared to muscle cells (Lassen, 2004). Serum ALT activity is said also too low to measured accurately in the horse, hence it's of little diagnostic importance (Lassen, 2008). Alkaline phosphatase (ALP) occurs in every tissue but its highest levels are found in the liver, bone, intestine, kidney and placenta. When serum ALP activity increases in dogs, cats and horses, it is most probably as a result of hepatocellular injury and/or biliary obstruction. Increased serum ALP occurs following administration of glucocorticoids, cholestasis, and in conditions characterized by increased osteoblastic activity such as in primary and secondary hyperthyroidism, bone healing and osteosarcoma (Stockham and Scott, 2008). It is elevated during recovery stages of acute toxic liver injury and in bile duct hyperplasia (Stockham and Scott, 2008). It is also useful in diagnosis of degenerative hepatic disease and infectious diseases of horses such as equine salmonellosis (Coles, 1986).

Bilirubin is the main bile pigment found in the serum of domestic animals (Coles, 1986). It originates from aged and defective red blood cells engulfed and lyzed by the macrophages of spleen, liver and bone marrow. The liver is responsible for its conjugation and excretion. Serum bilirubin determination is of great importance in classifying icterus and evaluates the response of the liver to therapy (Coles, 1986). Hyperbilirubinaemia and hyperbilibinuria occur in haemolytic disorders, intra-hepatic or extra-hepatic biliary obstruction, in acute/chronic hepatic disease and in fasting or anorexia in horses (Engelking, 1993). Increase in serum total bilirubin is seen in diseases such as Theileria's disease in horses (serum hepatitis), equine salmonellosis and cholangiohepatitis (Palmer, 1987).

Alterations in serum protein values are observed in association with both hepatic and renal diseases and these alterations are attributed to a decrease in the quantity of albumin (Coles, 1986). Hypoproteinemia is commonly associated with haemorrhage, malnutrition, malabsorption of dietary proteins and loss of albumin (Coles, 1986). Hyperalbuminemia is seen in acute dehydration and shock. Hypoproteinemia may also result from deficiency of dietary protein and albumin synthesis due to a decreased functional hepatic mass. Decreased albumin concentration is seen in parasitized and/or ascitic animals, and in extensive burns and severe haemorrhage. Increased levels of serum globulins (gamma) reflect a response of the reticuloendothelial system to antigenic stimulation (OECD, 2000).

The liver plays an important role in cholesterol synthesis, esterification and excretion (Coles, 1986). In horses, hypocholesterolemia has been observed in a variety of liver diseases and in condition of decreased cholesterol production by hepatocytes due to a reduction in the functional hepatic mass. Hypocholesterolemia is also seen in plasma cell myeloma and has been associated with anorexia and weight loss in affected horses (Edwards et al., 1993). Hypercholesterolemia occurs in condition of increased cholesterol production by hepatocytes seen in equine hyperlipidemia (Watson et al., 1992; Mogg and Palmer, 1995), hypothyroidsm, acute pancreatitis, cholestasis, and hyperadrenocorticism (Stockham and Scott, 2008).

Because of the strategic location of the liver and its multidimensional function, the liver is prone to many diseases. These diseases could be autoimmune, nutritional, metabolic, degenerative, inflammatory, infectious, inherited, and neoplastic. Also, the liver can be damaged by drugs, aflatoxins, pyrolizidine toxicosis and carbon tetrachloride poisoning in horses (West, 1996, Handan; Mehmet, 2009). Hepatic disease/damage is common in large animals and its clinical manifestation is often not outwardly characteristic hence the need for this study. Also, a search through available literature revealed paucity of information on specific biochemical markers of liver damage in spent horses. Therefore, this present study reports observations on the activities of some serum enzymes and the levels of some biochemical parameters in spent horses with liver damage. 


\section{Materials and Methods}

A total of 100 adult horses of either sex were evaluated in the study. The 100 horses were horses bought on the days of research visit to the Obollo Afor horse Lairage, Udenu Local Government Area, Enugu State, Nigeria located between latitude $6^{\circ} 54^{\prime} 56^{\prime \prime}$ north and longitude $7^{\circ} 30^{\prime} 55^{\prime \prime}$. Obollo Afor horse market has both a horse lairage and a slaughter slab where Nigerian local (Arewa) breed of horses and their crosses with Arabian, Dongola, Barb-arab and Sudanese breeds are kept, sold and also slaughtered for meat. The research visits were made once a week for a period of 24 weeks. All horses bought on each day of visit were evaluated. Each of the horses was physically examined, aged before blood samples were collected for serum biochemistry evaluations. The blood samples were dispensed into clean plain glass test tubes and allowed to stand for one hour at room temperature to clot. Serum for the assays was thereafter separated from clot by centrifugation. All the clinical biochemistry determinations were carried out immediately after separation of the serum from clot.

The clinical biochemistry determinations were carried out using commercial test kits, Quimica Clinica Aplicada (QCA) test kits (QCA, Spain), Randox tests kits (Randox, UK) for total proteins and albumin, and a digital colorimeter (Lab-tech, India). Determination of the serum alanine aminotransferase (ALT) and aspartate aminotransferase (AST) activities were based on the Reitman-Frankel method (Reitman and Frankel, 1957). The determination of serum alkaline phosphatase (ALP) activity was based on the phenolphthalein monophosphate method (Babson et al., 1966) while the total bilirubin determination was based on the Jendrassik-Grof method (Doumas et al., 1973). The total serum proteins were determined by the direct Biuret method (Lubran, 1978) and the serum albumin was determined by the bromocresol green method (Doumas et al., 1971). The serum globulin was calculated as the difference between the serum total proteins and serum albumin (Colville, 2002) while the serum total bilirubin was determined by the Jendrassik-Grof method (Doumas et al., 1973). The serum urea was determined by the Berthelot-Searcy method (Fawcett and Scott, 1960). The serum cholesterol was determined by the enzymatic colorimetric method (Allain et al., 1974).

Based on the outcome of the serum biochemistry evaluation, the horses were assigned into 3 groups namely: apparently healthy horses (Group 1) which were 61, horses with biochemical markers of acute liver damage (Group 2) which were 4 , while horses with biochemical markers of chronic liver damage (Group 3) were 14. The remaining 21 horses were in poor body condition and the values obtained from their serum sample analysis were either higher or lower than reference values obtained for Nigerian horses (Ihedioha and Agina, 2013). These 21 horses were excluded from the study.

\section{Data analysis}

Data generated from the study were subjected to appropriate statistics using SPSS 17.0. Analysis of data on apparently healthy horses, horses with biochemical markers of acute liver damage and horses with biochemical markers of chronic liver damage were carried out using one way analysis of variance (ANOVA) and variant means were separated by the least significant difference (LSD) method and Duncan multiple range test. Significant difference was accepted at $\mathrm{p}<0.05$.

\section{Results}

The horses with biochemical markers of acute liver damage showed significantly $(\mathrm{p}<0.05)$ higher mean serum aspartate aminotransferase, alanine aminotransferase, alkaline phosphatase and total bilirubin values than those of horses with biochemical markers of chronic liver damage and apparently healthy spent horses (Table 1). The horses with biochemical markers of chronic liver damage had significantly $(\mathrm{p}<0.05)$ lower mean serum alanine aminotransferase value, creatinine and serum urea values when compared to those of horses with biochemical markers of acute liver damage and apparently healthy horses (Tables 1 and 2). The mean serum albumin value of horses with biochemical markers of acute liver damage was significantly $(\mathrm{p}<0.05)$ lower than that of apparently healthy spent horses (Table 2). The mean serum creatinine value of horses with biochemical markers of acute and chronic liver damage was significantly $(p<0.05)$ lower than that of apparently healthy horses (Table 2). The mean total bilirubin value of horses with chronic liver damage did not differ significantly $(p>0.05)$ from that of acute liver damage and apparently healthy spent horses. There were no significant $(p>0.05)$ differences between the mean serum total protein, globulin and cholesterol values of the horses with biochemical markers of acute liver damage, chronic liver damage, and apparently healthy spent horses (Table 2).

Table 1. Serum enzyme activities of spent horses with liver damage compared to apparently healthy spent horses

\begin{tabular}{cccc}
\hline $\begin{array}{c}\text { Serum biochemistry } \\
\text { parameters }\end{array}$ & $\begin{array}{c}\text { Horses with acute liver damage } \\
(\mathrm{n}=4)\end{array}$ & $\begin{array}{c}\text { Horses with chronic liver damage } \\
(\mathrm{n}=14)\end{array}$ & $\begin{array}{c}\text { Apparently healthy spent horses } \\
(\mathrm{n}=61)\end{array}$ \\
\hline $\begin{array}{c}\text { Aspartate aminotransferase } \\
(\mathrm{IU} / \mathrm{L})\end{array}$ & $120.29 \pm 1.11^{\mathrm{a}}$ & Means \pm Standard error & $93.09 \pm 1.12^{\mathrm{b}}$ \\
$\begin{array}{c}\text { Alanine aminotransferase } \\
(\mathrm{IU} / \mathrm{L})\end{array}$ & $25.87 \pm 1.36^{\mathrm{a}}$ & $89.54 \pm 3.54^{\mathrm{b}}$ & $9.48 \pm 0.59^{\mathrm{c}}$ \\
$\begin{array}{c}\text { Alkaline phosphatase } \\
(\mathrm{IU} / \mathrm{L})\end{array}$ & $178.76 \pm 16.42^{\mathrm{a}}$ & $2.21 \pm 0.38^{\mathrm{b}}$ & $70.19 \pm 2.54^{\mathrm{b}}$ \\
\hline
\end{tabular}

${ }_{a, b, c, c}$ Different superscripts in a row indicate significant difference between the means $(\mathrm{p}<0.05)$. 
Table 2. Levels of some biochemical parameters of spent horses with liver damage compared to apparently healthy spent horses

\begin{tabular}{|c|c|c|c|}
\hline $\begin{array}{l}\text { Serum biochemistry } \\
\text { parameters }\end{array}$ & $\begin{array}{l}\text { Horses with acute liver damage } \\
\qquad(\mathrm{n}=4)\end{array}$ & $\begin{array}{l}\text { Horses with chronic liver damage } \\
\qquad(\mathrm{n}=14)\end{array}$ & $\begin{array}{l}\text { Apparently healthy spent horses } \\
\qquad(\mathrm{n}=61)\end{array}$ \\
\hline & & Means \pm Standard error & \\
\hline Total protein $(\mathrm{g} / \mathrm{dl})$ & $6.30 \pm 0.13$ & $6.42 \pm 0.10$ & $6.93 \pm 0.07$ \\
\hline Albumin (g/dl) & $2.94 \pm 0.14^{a}$ & $3.19 \pm 0.13^{\mathrm{ab}}$ & $3.37 \pm 0.05^{\mathrm{b}}$ \\
\hline Globulin (g/dl) & $3.35 \pm 0.02$ & $3.23 \pm 0.16$ & $3.49 \pm 0.08$ \\
\hline Total cholesterol $(\mathrm{mg} / \mathrm{dl})$ & $117.46 \pm 1.06$ & $107.32 \pm 5.39$ & $108.32 \pm 3.41$ \\
\hline Creatinine $(\mathrm{mg} / \mathrm{dl})$ & $0.67 \pm 0.13^{\mathrm{a}}$ & $1.05 \pm 0.09^{\mathrm{b}}$ & $1.32 \pm 0.04^{c}$ \\
\hline Total bilirubin $(\mathrm{mg} / \mathrm{dl})$ & $6.70 \pm 0.22^{a}$ & $4.00 \pm 0.40^{\mathrm{b}}$ & $3.53 \pm 0.13^{b}$ \\
\hline Urea $(\mathrm{mg} / \mathrm{dl})$ & $31.05 \pm 2.78^{\mathrm{a}}$ & $15.41 \pm 2.24^{\mathrm{b}}$ & $32.36 \pm 0.88^{\mathrm{a}}$ \\
\hline
\end{tabular}

\section{Discussion}

The significantly elevated serum activities of aspartate aminotransferase and alanine aminotransferase recorded for horses with acute liver damage could be attributed to the fact that aspartate aminotransferase and alanine aminotransferase are cytoplasmic enzymes found in hepatocytes, and insult/injury to the hepatocytes can lead to an appreciable increase in their serum activities (Coles, 1986; Stockham and Scott, 2008). The finding of normal serum AST activity and low ALT activity in horses with chronic liver damage is not clearly understood. This is because it has been reported that in chronic liver damage, ALT and AST activities may be entirely within the reference range, even in the presence of cirrhosis (CLF, 2017). Also, the low ALT activity in these spent horses is of little or no significance as ALT is known to be low in liver cells of horses and is not helpful in evaluating chronic liver disease (Lassen, 2004; Eclinpath, 2017). The increase in serum alkaline phosphatase activity recorded for horses with acute liver damage may be associated with acute damage to the hepatobiliary tract or cholestasis (Naylor et al., 2012). This is because alkaline phosphatase is primarily excreted through the biliary duct and serum activity increases when there is intrahepatic or extrahepatic obstruction to bile flow, and/or hepatobiliary injury in the horse (Milne, 1993). The normal serum ALP activity reported for horses with chronic liver damage could be due to the fact that ALP is a marker of cholestasis and that chronic liver damage alone has little effect on it (Lavioe and Hinchcliff, 2008). Hyperbilirubinemia could be attributed to the decreased functional ability of the liver to conjugate bilirubin for clearance from the blood stream (Stockham and Scott, 2008). The finding of a normal serum urea level of horses with acute liver damage is not completely understood. In horses with chronic liver damage, serum urea is decreased due to a decreased conversion of ammonia to urea (Lavioe and Hinchcliff, 2008), leading to consequent elevation in blood ammonia level.

The hypoalbuminemia recorded for horses with acute liver damage is not in agreement with the report of Lavioe and Hinchcliff (2008), who recorded hypoalbuminaemia in conditions of chronic liver damage and end stage liver disease. The reason for the decrease in albumin concentration in chronic liver damage could be due to decreased synthesis of albumin by few remaining hepatocytes. The finding of normal total protein and albumin levels observed in horses with chronic liver damage is in agreement with Parraga et al. (1995) and McGorum et al. (1999) who recorded normal total proteins and albumin levels in horses with primary hepatic disease. The normal globulin level recorded in horses with acute and chronic liver damage in this study is in agreement with the reports of Pearson (1990) and Parraga et al. (1995) who recorded hyperglobulinemia in horses with liver failure, as globulin tends to increase only in end-stage liver disease or liver failure (Lavioe and Hinchcliff, 2008). The finding of a cholesterol value within the reference range in horses with acute liver damage is normal because cholesterol level is only altered (decreased) in conditions of hepatic insufficiency (Lavioe and Hinchcliff, 2008).

\section{Conclusions}

Based on the results of this study, it was concluded that in spent horses, acute liver damage is characterized by increased serum ALT, AST and ALP activities, and a decrease in creatinine level, hyperbilirubinemia, slight hypoalbuminemia, normal total protein, globulin and cholesterol levels while chronic liver damage is characterized by decreased serum ALT activity, normal serum AST and ALP activities, decreased serum urea level, normal total protein, albumin, globulin, total bilirubin and cholesterol levels. These findings could be of diagnostic importance to veterinarians and equine clinicians.

\section{References}

Allain CC, Poon LS, Chan CS, Richmond W, Fu PU (1974). Enzymatic determination of total cholesterol. Clinical Chemistry 20:470-475.

Babson AL, Greeley SJ, Coleman CM, Philips GE (1966). Phenolphthalein monophosphate as a substrate for serum alkaline phosphatase. Clinical Chemistry 12:482-490.

Bain PJ (2003). Liver. In: Latimer K.S, Mahaffey EA, Prasse KW (Eds). Duncan and Prasse's Veterinary Laboratory Medicine, Clinical Pathology, $4^{\text {th }}$ ed. Ames, IowaState Press pp 193-214.

Blass KG, Thiebert RJ, Lam LK (1974). A study of the mechanism of the Jaffe reaction: Journal ofClinical Biochemistry 12:336-343.

Brown BA (1976). Direct methods for platelet counts- Rees and Ecker method. In: Brown BA (Ed). Haematology: Principles and Procedures, $2^{\text {nd }}$ ed. Lea and Febiger, Philadelphia pp 101-103.

Brunzell JD, Davidson M, Furberg CD, Goldberg RB, Howard BV, Stein JH, Witztum JL (2008). Lipoprotein management in patients with cardio metabolic risk: Consensus statement from the American diabetes association and the American College of Cardiology Foundation. Diabetes Care 31:811-822. 
Coles EH (1986). Veterinary clinical pathology. $4^{\text {th }}$ ed. WB Saunders, Philadelphia.

Colville J (2002). Blood chemistry. In: Hendrix CM (Ed). Laboratory procedures for Veterinary Technicians. $4^{\text {th }} \mathrm{ed}$. Mosby, St. Louis pp 75103.

Doumas BT, Perry BW, Sasse EA, Straumfjord Jr JV (1973). Standardization in bilirubin assays: Evaluation of selection methods and stability of bilirubin solutions. Clinical Chemistry 19:984993

Doumas BT, Watson WA, Biggs HG (1971). Albumin standards and the measurement of serum albumin with bromocresol green. Clinica ChimicaActa31:87-96.

Duncan JR, Prasse KW (1986). Veterinary laboratory medicine. $2^{\text {nd }} \mathrm{ed}$, University Press, Ames, Iowa State.

Edwards DF, Parker JW, Wilkinson JE, Helman G (1993). Plasma cell myeloma in the horse. Journal of Veterinary Internal Medicine 7:169176.

Engelking LR (1993). Equine fasting hyperbilirubinemia. Advances in VeterinaryScience and Comparative Medicine 37:115-125.

Fawcett JK, Scott JE (1960). A rapid and precise method for the determination of urea. Journal of Clinical Pathology 13:156-159.

Frank N, Andrews FM, Elliott SB, Lew J, Boston RC (2005). Effects of rice bran oil on plasma lipid concentrations, lipoprotein composition and glucose dynamics in mares. Journal of Animal Science 83:2509-2518.

Handan HA, Mehmet S (2009). Investigations on hepatic insufficiency in serum-producinghorses and prognostic importance of some clinical and biochemical parameters. Journal of Animal and Veterinary Advances 8(6):1198-1203.

Ihedioha JI, Anosa VO, Esievo KAN (2013). Prevalence of and clinic pathologic findings associated with ascites in dogs in Enugu State, Nigeria. Comparative Clinical Pathology 22:185-193.

Kaneko JJ (2008). Veterinary clinical biochemistry of domestic animals. $6^{\text {th }}$ ed. Elsevier Inc.

Klein B, Read PA, Babson AL (1960). Rapid method for the quantitative determination of serum alkaline phosphatase. Clinical Chemistry 6:269275.

Lubran MM (1978). The measurement of total serum proteins by the Biuret method. Annals of Clinical Laboratory Science 8:106-110.

McGorum BC, Murphy D, Love S, Milne EM (1999). Clinicopathological features of equine primary hepatic disease: A review of 50 cases. Veterinary Record 145:134139.

Messer NT, Johnson PJ (1994). Idiopathic acute hepatic disease in horses: 12 cases (1982-1992). Journal of American Veterinary Medical Association 204:1934-1937.

Milne EM (1993). Differential diagnosis of hepatic disorders in horses. Equine Practice 2:121-144.

Mogg TD, Palmer JE (1995). Hyperlipidemia, hyperlipaemia and hepatic lipidosis in American miniature horses: 23 cases (1990-1994). Journal of American Veterinary Medical Association 207:604-607.
Naylor RJ, Hillyer LL, Hillyer MH (2012). Laboratory diagnostics. In:: Coumbe KM (Ed). Equine Veterinary Nursing Manual, $2^{\text {nd }} \mathrm{ed}$. WileyBlackwell, West Sussex, United Kingdom pp 201-225.

NCEP (National Cholesterol Education Program) (2002). Third Report of the National Cholesterol Education Program (NCEP). Expert panel on Detection, Evaluation and Treatment of High Blood Cholesterol in Adults-Adult Treatment Panel III, Final Report, NCEP, National Heart, Lung, and Blood Institute, National Institutes of Health, USA.

OECD (2000). Guidance Notes for the analysis and evaluation of repeat dose toxicity studies. Environment, Health and Safety Publications Series on Testing and Assessment, Environment Directorate, Organization for Economic Cooperation and Development (OECD), Paris pp 27-72.

Palmer JE (1987). Salmonellosis. In: Robinson NE (Ed). Current Therapy in Equine Medicine. WBS Saunders Company, Philadelphia pp 88-91.

Parraga ME, Carlson GP, Thurmond M (1995). Serum protein concentrations in horses with severe liver disease: A retrospective study and review of the literature. Journal of Veterinary Internal Medicine 9:154-161.

Pearson EG (1990). Diagnosis of liver disease. In: Smith BP (Ed). Large Animal Internal Medicine. C. V.Mosby,St.Louis pp 837-843.

Ramaiah SK, Harvey JW, Giguere S, Franklin RP, Crawford PC (2003). Intravascular hemolysis associated with liver disease in a horse with marked neutrophil hypersegmentation. Journal of Veterinary Internal Medicine 17:360-363.

Reitman S, Frankel S (1957). A colorimetric method for determination of serum glutamic oxaloacetic and glutamic pyruvic transaminase. American Journal of Clinical Pathology pp 28:56-62.

Schalm OW, Jain NC, Carroll EJ (1975). Veterinary hematology. Lea and Febiger, Philadelphia.

Schoen FJ (2004). Atherosclerosis. In: Kumar V, Abbas, AK, Fausto N (Eds). Robbins and Cotran pathologic basis of disease, $7^{\text {th }}$ ed. WB Saunders, Philadelphia pp 515-525.

Sirois M (1995). Veterinary clinical laboratory procedures. Mosby’s Fundamentals of Veterinary Technology, Mosby’s Year-bookInc.

Stockham SL, Scott MA (2008). Fundamentals of veterinary clinical pathology. $2^{\text {nd }}$ ed. Blackwell Publishing Iowa, USA.

Turgut K, Ok M (1997). Icterus in horses. Veterinary Gastroenterology. Mikro Dizgi Company, Konya, Turkey pp 551-560.

Watson TDG, Murphy D, Love S (1992). Equine hyperlipaemia in the United Kingdom: Clinical features and blood biochemistry of 18 cases. Veterinary Record 131:48-51.

West HJ (1996). Clinical and pathological studies in horses with hepatic disease.Equine Veterinary Journal 28:146-156. 